\title{
Front Matter: Volume 9025
}

, "Front Matter: Volume 9025," Proc. SPIE 9025, Intelligent Robots and Computer Vision XXXI: Algorithms and Techniques, 902501 (3 February 2014); doi: 10.1117/12.2057496

SPIE Event: IS\&T/SPIE Electronic Imaging, 2014, San Francisco, California, United SPIE. States 


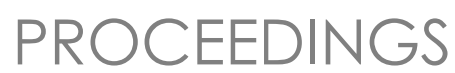

IS\&T / SPIE

Electronic

Imaging

SCIENCE AND TECHNOLOGY

\section{Intelligent Robots and Computer Vision XXXI: Algorithms and Techniques}

Juha Röning

David Casasent

Editors

4-6 February 2014

San Francisco, California, United States

Sponsored by

IS\&T-The Society for Imaging Science and Technology

SPIE

Published by

SPIE 
The papers included in this volume were part of the technical conference cited on the cover and title page. Papers were selected and subject to review by the editors and conference program committee. Some conference presentations may not be available for publication. The papers published in these proceedings reflect the work and thoughts of the authors and are published herein as submitted. The publishers are not responsible for the validity of the information or for any outcomes resulting from reliance thereon.

Please use the following format to cite material from this book:

Author(s), "Title of Paper," in Intelligent Robots and Computer Vision XXXI: Algorithms and Techniques, edited by Juha Röning, David Casasent, Proceedings of SPIE-IS\&T Electronic Imaging, SPIE Vol. 9025. Article CID Number (2014)

ISSN: 0277-786X

ISBN: 9780819499424

Copublished by

SPIE

P.O. Box 10, Bellingham, Washington 98227-0010 USA

Telephone +1 3606763290 (Pacific Time) · Fax +1 3606471445

SPIE.org

and

IS\&T-The Society for Imaging Science and Technology

7003 Kilworth Lane, Springfield, Virginia, 22151 USA

Telephone +1 7036429090 (Eastern Time) · Fax +1 7036429094

imaging.org

Copyright (C) 2014, Society of Photo-Optical Instrumentation Engineers and The Society for Imaging Science and Technology.

Copying of material in this book for internal or personal use, or for the internal or personal use of specific clients, beyond the fair use provisions granted by the U.S. Copyright Law is authorized by the publishers subject to payment of copying fees. The Transactional Reporting Service base fee for this volume is $\$ 18.00$ per article (or portion thereof), which should be paid directly to the Copyright Clearance Center (CCC), 222 Rosewood Drive, Danvers, MA 01923. Payment may also be made electronically through CCC Online at copyright.com. Other copying for republication, resale, advertising or promotion, or any form of systematic or multiple reproduction of any material in this book is prohibited except with permission in writing from the publisher. The CCC fee code is 0277-786X/14/\$18.00.

Printed in the United States of America.

Paper Numbering: Proceedings of SPIE follow an e-First publication model, with papers published first online and then in print and on CD-ROM. Papers are published as they are submitted and meet publication criteria. A unique, consistent, permanent citation identifier (CID) number is assigned to each article at the time of the first publication. Utilization of CIDs allows articles to be fully citable as soon as they are published online, and connects the same identifier to all online, print, and electronic versions of the publication. SPIE uses a six-digit CID article numbering system in which:

- The first four digits correspond to the SPIE volume number.

- The last two digits indicate publication order within the volume using a Base 36 numbering

system employing both numerals and letters. These two-number sets start with 00, 01, 02, 03, 04, $05,06,07,08,09,0 A, 0 B \ldots$. OZ, followed by 10-1Z, 20-2Z, etc.

The CID Number appears on each page of the manuscript. The complete citation is used on the first page, and an abbreviated version on subsequent pages. Numbers in the index correspond to the last two digits of the six-digit CID Number. 


\section{Contents}

vii Conference Committee

\section{SESSION 1 INTELLIGENT MOBILE ROBOT METHODS AND ADVANCEMENTS}

902502 Adaptation of human routines to support a robot's tasks planning and scheduling [9025-1]

A. Tikanmäki, Univ. of Oulu (Finland); S. T. Feliu, Univ of Oulu (Finland); J. Röning, Univ. of Oulu (Finland

902503 A novel lidar-driven two-level approach for real-time unmanned ground vehicle navigation and map building [9025-2]

C. Luo, M. Krishnan, M. Paulik, B. Cui, X. Zhang, Univ. of Detroit Mercy (United States)

902504 The 21st annual intelligent ground vehicle competition: robotists for the future [9025-3]

B. L. Theisen, U.S. Army Tank Automotive Research, Development and Engineering Ctr. (United States)

902506 Self-localization for an autonomous mobile robot based on an omni-directional vision system [9025-5]

S.-Y. Chiang, K.-Y. Lin, T.-L. Chia, Ming Chuan Univ. (Taiwan)

\section{SESSION 2 COMPUTER VISION ALGORITHMS AND APPLICATIONS}

902507 High-speed object matching and localization using gradient orientation features [9025-6]

X. XU, P. van Beek, X. Feng, Sharp Labs. of America, Inc. (United States)

902508 Automatic lip reading by using multimodal visual features [9025-7]

S. Takahashi, J. Ohya, Waseda Univ. (Japan)

902509 A Viola-Jones based hybrid face detection framework [9025-8]

T. M. Murphy, R. Broussard, R. Schultz, R. Rakvic, H. Ngo, U.S. Naval Academy (United States)

9025 OA Towards automatic identification of mismatched image pairs through loop constraints [9025-9]

A. Elibol, Yildiz Technical Univ. (Turkey); J. Kim, KAIST (Korea, Republic of); N. Gracias,

R. Garcia, Univ. de Girona (Spain)

$9025 \mathrm{OB} \quad$ Using short-wave infrared imaging for fruit quality evaluation [9025-10]

D. Zhang, Sun Yat-Sen Univ. (China); D.-J. Lee, A. Desai, Brigham Young Univ. (United States) 
9025 OD Planning perception and action for cognitive mobile manipulators (Invited Paper) [9025-13] A. Gaschler, S. Nogina, Technische Univ. München (Germany); R. P. A. Petrick, Univ. of Edinburgh (United Kingdom); A. Knoll, Technische Univ. München (Germany)

\section{SESSION 4 LOCALIZATION, TRACKING, AND SCENE ANALYSIS}

9025 OF Motion lecture annotation system to learn Naginata performances [9025-15]

D. Kobayashi, Mie Univ. (Japan); R. Sakamoto, Mie Univ. Hospital (Japan); Y. Nomura, Mie Univ. (Japan)

9025 OG Illumination-robust people tracking using a smart camera network [9025-16] N. Bo Bo, P. Van Hese, J. Guan, S. Gruenwedel, J. Niño-Castañeda, D. Van Cauwelaert, D. Van Haerenborgh, P. Veelaert, W. Philips, Univ. Gent (Belgium)

9025 Ol Using probabilistic model as feature descriptor on a smartphone device for autonomous navigation of unmanned ground vehicles [9025-18]

A. Desai, D.-J. Lee, Brigham Young Univ. (United States)

9025 OK Classification and segmentation of orbital space based objects against terrestrial distractors for the purpose of finding holes in shape from motion 3D reconstruction [9025-20]

T. N. Mundhenk, A. Flores, H. Hoffman, HRL Labs., LLC (United States)

\section{SESSION 5 3D VISION}

$9025 \mathrm{OL} \quad$ Discrete and continuous curvature computation for real data [9025-21]

D. Colbry, Michigan State Univ. (United States); N. Shrikhande, Central Michigan Univ. (United States)

9025 OM An evaluation of attention models for use in SLAM [9025-22]

S. Dodge, L. Karam, Arizona State Univ. (United States)

902500 SDTP: a robust method for interest point detection on 3D range images [9025-24]

S. Wang, L. Gong, H. Zhang, Y. Zhang, H. Ren, Samsung Advanced Institute of Technology (China); S.-M. Rhee, H.-E. Lee, Samsung Advanced Institute of Technology (Korea, Republic of)

9025 OP Real time moving object detection using motor signal and depth map for robot car [9025-25]

H. Wu, W.-C. Siu, The Hong Kong Polytechnic Univ. (Hong Kong, China) 
$90250 Q \quad$ Research and development of Ro-boat: an autonomous river cleaning robot [9025-26] A. Sinha, Omnipresent Robot Technologies Pvt. Ltd. (India); P. Bhardwaj, Manav Rachna College Of Engineering (India); B. Vaibhav, Indian Institute Of Technology Guwahati (India); N. Mohommad, National Institute Of Technology, Warangal (India)

9025 OR Real-time, resource-constrained object classification on a micro-air vehicle [9025-27] L. Buck, L. Ray, Dartmouth College (United States)

9025 OT New vision system and navigation algorithm for an autonomous ground vehicle [9025-29] H. Tann, B. Shakya, A. C. Merchen, B. C. Williams, A. Khanal, J. Zhao, D. J. Ahlgren, Trinity College (United States)

9025 OU An effective trace-guided wavefront navigation and map-building approach for autonomous mobile robots [9025-30] C. Luo, M. Krishnan, M. Paulik, Univ. of Detroit Mercy (United States); G. E. Jan, National Taipei Univ. (Taiwan)

\section{INTERACTIVE PAPER SESSION}

9025 OW An intelligent hybrid behavior coordination system for an autonomous mobile robot [9025-32]

C. Luo, M. Krishnan, M. Paulik, S. Fallouh, Univ. of Detroit Mercy (United States)

9025 0X Increasing signal-to-noise ratio of registered images by using light spatial noise portrait of camera's photosensor [9025-33]

N. N. Evtikhiev, P. A. Cheremkhin, V. V. Krasnov, V. G. Rodin, S. N. Starikov, National Research Nuclear Univ. MEPhl (Russian Federation)

9025 OY Color back projection for fruit maturity evaluation [9025-34]

D. Zhang, Sun Yat-Sen Univ. (China); D.-J. Lee, A. Desai, Brigham Young Univ. (United States)

$90250 Z$ Unmanned ground vehicle: controls and dynamics [9025-35]

E. Attarwala, P. Maheshwari, K. Keshav, P. Jain, A. Gupta, K. Gupta, R. Yadav, Indian Institute of Technology Bombay (India)

Author Index 
SPIE-IS\&T/ Vol. $9025902501-6$

Downloaded From: https://www.spiedigitallibrary.org/conference-proceedings-of-spie on 26 Apr 2023 Terms of Use: https://www.spiedigitallibrary.org/terms-of-use 


\title{
Conference Committee
}

\author{
Symposium Chair \\ Sergio R. Goma, Qualcomm Inc. (United States) \\ Symposium Cochair
}

Sheila S. Hemami, Northeastern University (United States)

Conference Chairs

Juha Röning, University of Oulu (Finland)

David Casasent, Carnegie Mellon University (United States)

Conference Program Committee

Norbert Lauinger, CORRSYS 3D Sensors AG (Germany)

Dah Jye Lee, Brigham Young University (United States)

Charles A. McPherson, Draper Laboratory (United States)

Kurt S. Niel, Fachhochschule Wels (Austria)

Yoshihiko Nomura, Mie University (Japan)

Lucas Paletta, JOANNEUM RESEARCH Forschungsgesellschaft mbH (Austria)

Daniel Raviv, Florida Atlantic University (United States)

Bernard L. Theisen, U.S. Army Tank Automotive Research, Development and Engineering Center (United States)

Dili Zhang, Monotype Imaging (United States)

Session Chairs

1 Intelligent Mobile Robot Methods and Advancements

Juha Röning, University of Oulu (Finland)

David Casasent, Carnegie Mellon University (United States)

2 Computer Vision Algorithms and Applications

Kurt S. Niel, Upper Austria University of Applied Sciences (Austria)

3 Mobile Cognitive System

Lucas Paletta, JOANNEUM RESEARCH Forschungsgesellschaft mbH (Austria)

4 Localization, Tracking, and Scene Analysis

Terrell Nathan Mundhenk, HRL Laboratories, LLC (United States)

5 3D Vision

Yoshihiko Nomura, Mie University (Japan) 
6 Outdoor Robotics

Bernard L. Theisen, U.S. Army Tank Automotive Research, Development and Engineering Center (United States) 